Економічні науки: збірник наукових прачь Луцького національного технічного університету. - Серія "Регіональна економіка". - Випуск 16 (63). - Редкол.: відп. ред. д.е.н., професор Л.Л. Ковальська - Луиьк: ІВВ Луцького НТУ, 2019. - 173 с.

УДК 330.35

Завадська О.М., к.е.н., доцент

Луцький національний технічний університет

\title{
НЕТВОРКІНГ БІЗНЕСУ: ПОНЯТТЯ ТА ОСОБЛИВОСТІ
}

У статті розглянуто поняття нетворкінгу бізнесу, його важливість та актуальність в сучасному комерційному та безкомпромісному світі. Було розглянуто шляхи побудови взаємозв'язків між партнерами та встановлення домовленостей між ними, і доцільність їх використання.

Ключові слова: нетворкінг, бізнес, комунікаї, бізнес-зв'язки , клієнт.

\section{Zavadska O.}

\section{NETWORKING BUSINESS: CONCEPTS AND FEATURES}

The article deals with the notion of networking business, its importance and relevance in the modern commercial and uncompromising world, as one of the main skills of a successful person is the presence of connections, useful contacts through which people quickly solve their own and others' tasks. Few people have birth defects, usually this skill comes with life experience. The ways of building relationships between partners and establishing agreements between them were considered, and the feasibility of using them.

The world of business is constantly changing, including the negotiation style, corporate culture, management strategies, and thus the very rules of the game of doing business are subject to change. Any business tasks are always done in collaboration. Their success depends on the right choice of partners, employees, clients. Therefore, you should not rely on the case in the search for new dating, because there is networking - making useful connections and communicating with potentially useful for business people.

Networking when creating and formulating relationships require creative thinking and creativity. This is a very effective method of HR management, per provided that it is used systematically. It should be kept in mind that it will not start to produce effects in a short time, and as any process requires time and effort. However, the implications are in the form increasing the efficiency of staff, their satisfaction with working conditions, which will lead to expansion and production efficiency, it's worth it. Networking is a very important part of business. It helps to meet people, build relationships and to create a new base of partners and potential clients. Networking as a method of establishing contacts where communication serves a starting point, a way of self-education and self-development, is also the most effective and least expensive tool in human capital management to enhance business. 
Економічні науки: збірник наукових праць Луцького національного технічного університету. - Серія "Регіональна економіка". - Випуск 16 (63). - Редкол.: відп. ред. д.е.н., професор Л.Л. Ковальська - Луцьк : ІВВ Луцького НТУ, 2019. -173 с.

Key world: networking, business, communications, businesscommunications, customer.

\section{Завадская Е.}

\section{НЕТВОРКИНГ БИЗНЕСА:ПОНЯТИЕ И ОСОБЕННОСТИ}

В статье рассмотрено понятие нетворкинга бизнеса, его важность и актуальность в современном коммерческом и бескомпромиссном мире. Были рассмотрены пути построения взаимосвязей между партнерами и установление договоренностей между ними и целесообразность их использования. клиент.

Ключевые слова: нетворкинг, бизнес, комуникаии, бизнес-связи,

Постановка проблеми у загальному вигляді та ії зв'язок 3 важливими науковими та практичними завданнями. Розвиток сучасного світу вимагає розробки нової парадигми поведінки людей. Виходячи 3 цього, необхідно думати i діяти масштабно, приймати більш обгрунтовані системні рішення, орієнтовані на людські аспекти свідомості. На порядку денному алгоритми поведінки людей, які стають суб'єктами управління, відповідальними за все, що відбувається навколо, формуючи при цьому новий тип організації життя людства. Однією з інноваційних конструктивних ідей, реалізація якої допомагає підприємствам домогтися успіху, є нетворкінг. Нетворкінг - досить нове явище, яке потребує науковопрактичного забезпечення, завдяки чому може мати серйозні перспективи розвитку в сучасних умовах бізнесу, що спирається на вибудовування відносин на неформальній основі, довірі, дотриманні високої етики. Нетворкінг вимагає терпіння, йому можна навчитися, але знадобиться план дій i чітко визначені цілі.

Аналіз останніх досліджень, у яких започатковано вирішення проблеми.

Вивченням даного питання займалися такі українські практики як М. Шутак, Р. Андерсон, О. Кравцов, що ж до закордонних дослідників, то це викладачі бізнес-школи Колумбійського університету П. Інграм і М. Морріс, голова 
Економічні науки: збірник наукових праџь Луцького національного технічного університету. - Серія "Регіональна економіка". - Випуск 16 (63). - Редкол.: відп. ред. д.е.н., професор Л.Л. Ковальська - Луиьк: ІВВ Луиького НТУ, 2019. - 173 с.

венчурного фонду «Нексчурі Венчурес»(Nextury Ventures) I. Лаурсен, найуспішніший нетворкер у світі К. Ферацці [6].

Цілі статті. Розкрити сутність поняття «нетворкінг» та особливості щодо можливості його застосування в бізнесі.

Виклад основного матеріалу дослідження 3 повним обгрунтуванням отриманих наукових результатів.

Нетворкінг - один 3 новомодних термінів, які використовують на Заході. Звідси він перекочував в Україну, хоча саме явище вже давно було частиною нашої культури. Якщо перекладати буквально, виходить «плетіння мереж». Простою мовою - це створення навколо себе кола професіоналів, об'єднаних чимось загальним. Це можуть бути прагнення, погляди, професійні якості або галузь.

Простими словами нетворкінг - побудова мережі ділових зв'язків. Вибудовування відносин з людьми, при яких ви завжди можете звернутися за порадою, просунути свій товар в колі знайомств, отримати контакти цінного фахівця і т. д.

В Україні нетворкінг розуміють трохи по-іншому. Коли ви підходите на будь-якій конференції до людини, «перекидаючись» парою слів і залишаєте візитку - це не нетворкінг. Коли ви просто в двох словах говорите про те, де працюєте, це теж не те. Справжній нетворкінг - це поспілкуватися 3 людиною 1-2 години в спокійній обстановці, дізнатися, чим він займається, розповісти, чим займаєшся сам, i, якщо потрібно, дати кілька порад з особистого досвіду.

Справжній нетворкінг - це більше про стиль життя. Це означає, що ви будете оточувати себе людьми, які будуть тягнути вас вгору, допомагати вирішувати професійні завдання i ділитися власним досвідом [4].

Нетворкінг більше характерний для бізнес-спільноти або якихось професійних кіл. Коли створюються спільноти зі схожими інтересами та прагненнями, вони знайомляться один 3 одним, діляться досвідом, допомагають новачкам, іноді разом вирішують питання.

Нетворкінг чудово допомагає навіть у фріланссередовищі. Якщо ви в хороших відносинах з колегами і хоча б 
Економічні науки: збірник наукових праџь Луцького національного технічного університету. - Серія "Регіональна економіка". - Випуск 16 (63). - Редкол.: відп. ред. д.е.н., професор Л.Л. Ковальська - Луиьк: ІВВ Луиького НТУ, 2019. - 173 с.

кілька людей знаєте ближче, ніж по спілкуванню в коментарях, ви завжди можете запитати поради, поділитися досвідом, а деякі колеги можуть направити замовника до вас, якщо самі не зможуть взятися за роботу.

Нетворкінг корисний всім, хто хоче професійно зростати в будь-якому бізнесі. Правильне оточення надає мотивацію, чужий досвід і підказки значно скорочують шлях до вершини, а допомога вашим хорошим знайомим може принести додаткові дивіденди в майбутньому.

$€$ теорія, яка допомагає зрозуміти силу нетворкінгу: теорія 6 рукостискань.

Її суть в наступному: опосередковано, через знайомих, ми можемо зв'язатися 3 будь-якою людиною через 5 інших. Іншими словами, ми знайомі 3 англійською королевою через 5 «знайомих наших знайомих».

3 цього випливає наступний, простий висновок: практично $з$ будь-якою людиною ми можемо знайти точки дотику. А це значить, що ми завжди можемо знайти спільну мову, спільних знайомих, спільні інтереси 3 кожним зустрічним. А це вже дозволяє заводити корисних знайомих завжди і всюди.

Види нетворкінгу

Деякі фахівці в області ділового спілкування виділяють 3 види нетворкінгу [1;2; 7]:

- позитивний;

- негативний;

- щось середнє.

Позитивний спрямований на придбання нових знайомств виключно для того, щоб бути корисним. Це варіант для тих, хто хоче більше віддавати, ніж отримувати. Спосіб підходить для професіоналів своєї справи, які можуть спілкуватися 3 людьми, що стоять нижче по соціальних сходах, всіляко допомагати їм і підтримувати.

Зазвичай такі люди збирають навколо себе більш «слабких» людей, які зараз менш успішні, ніж вони. Для чого? Щоб допомагати, підтримувати i в майбутньому, 
Економічні науки: збірник наукових праџь Луцького національного технічного університету. - Серія "Регіональна економіка". - Випуск 16 (63). - Редкол.: відп. ред. д.е.н., професор Л.Л. Ковальська - Луцьк: ІВВ Луцького НТУ, 2019. - 173 с.

можливо, отримати від цього якийсь результат. Зв'язки вирішують все» - це одна 3 найдавніших бізнес-мудростей. Якщо ви знайомі 3 великою кількістю людей - зможете вирішити будь-яку проблему. I, навпаки: вміння створювати зв'язки відсутні - у бізнесі вам практично немає що робити $[3 ; 5]$.

Нетворкінг (анг.networking) - соціальна i професійна діяльність, спрямована на те, щоб за допомогою кола друзів і знайомих максимально швидко і ефективно вирішувати складні життєві завдання і бізнес-питання (знаходити клієнтів, наймати кращих співробітників, залучати інвесторів) [2].

Нетворкінг дозволяє обмінятися досвідом, дізнатися про нові послуги, отримати рекомендації, проконсультуватись 3 того чи іншого питання, вирішити важливу проблему. Крім того, нетворкінг - це ще одна можливість вловлювати важливі тренди в сфері управління персоналом. Постійне спілкування 3 представниками інших компаній буде тримати менеджера 3 персоналу в курсі подій і очікуваних заходів, показувати тенденції на ринку праці та в конкретній сфері. Виділимо основні шляхи для впровадження нетворкінгу в сфері управління персоналом для вітчизняних підприємств [2]:

1. Формування єдиного комунікаційного простору за допомогою створення інтернет-ресурсу, котрий агрегує інформацію про всі HR-заходи різного рівня, що проводяться, який буде націлений не тільки на наукову i професійну підтримку діяльності управлінців, але і бізнес-спільноти;

2. Розробка програми тренінгів 3 нетворкінгу для управлінців;

3. Використання коворкінгових майданчиків для обміну досвідом між управлінцями місцевих компаній і проведення speed-dating.

Висновки. Таким чином, нетворкінг - це інструмент, гостро необхідний для розвитку професійного співтовариства i підвищення професійного рівня управлінців, для вироблення загальних стандартів роботи, лобіювання професійних інтересів i ідей та ефективного бізнесу. Завдяки нетворкінгу відбувається 
Економічні науки: збірник наукових праць Луцького національного технічного університету. - Серія "Регіональна економіка". - Випуск 16 (63). - Редкол.: відп. ред. д.е.н., професор Л.Л. Ковальська - Луиьк: ІВВ Луиького НТУ, 2019. -173 с.

формування єдиного понятійного апарату, поширення передових стандартів роботи, здійснюється більш ефективне господарювання.

1. Резак Д. Связи решают все! Правила позитивного нетворкинга / Дарси Резак. М. : Альпина Бизнес Букс, 2012.

2. Нетворкинг - как инструмент расширения бизнеса [Електронний pecypc]. - Режим доступу : http://business.damotvet.ru/ marketing/22190.htm.

3. Fisher D. \& Vilas S. Power Networking. Bard Press The Riley Guide, 2000. URL: www.rileyguide.com. 4. Frishman R. Networking Magic/R. Frishman, J. Lublin. Adams Media, 2004.

4. Lipnack J., Stamps J. The age of the Network: Organizing Principles for the 21st Century. New York: Wiley, 1994.

5. Turniak G., Antosiewicz W. Praktyczny poradnik networkingu. Zbuduj sieć trwałych kontaktów biznesowych. - Wydawnictwo Helion, Gliwice, 2012.

6. Ферацці К. Ніколи не їжте наодинці та інші секрети успіху завдяки широкому колу знайомств. [Електронний ресурс] / Режим доступу: https://mybook.ru/author/kejt-ferracci-2/nikoli-neyizhte-naodinci-ta-inshi-sekretiuspihu/read/

7. Зак Д. Нетворкінг для інтровертів / Зак Д.. М.: Альпіна Бізнес Букс, 2012. 208 с. 3. Сполдінг Т. Зв'язки - не головне. На чому тримається міцний бізнес / Т. Сполдінг. М.: Кар'єра Прес, 2011. 288 с. 